
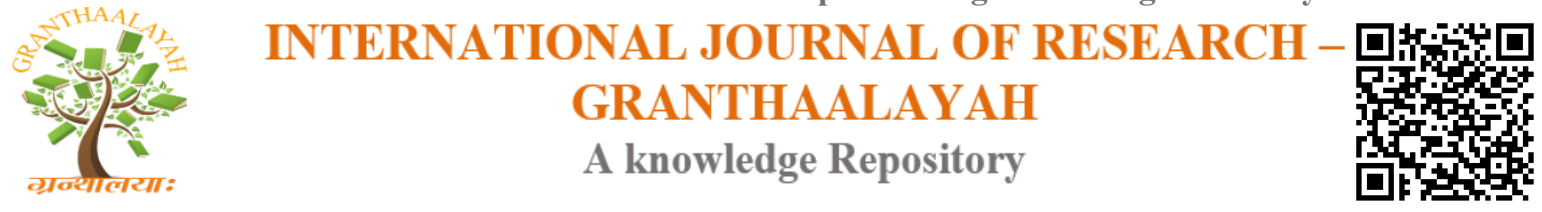

Social

\title{
REFLECTION OF GLOBAL VALUES IN ANTI-TORTURE IN THE CRIMINAL PROCEDURE CODE
}

\author{
Ibnu Artadi *1 \\ ${ }^{* 1}$ Faculty of Law, Universitas Swadaya Gunung Djati, Cirebon, Indonesia
}

\begin{abstract}
In line with the identity of "rechstaat" and "the rule of law", the law must recognize and guarantee human rights in order to establish a just order, because justice goes hand in hand with the structure of human rights. The realization of the Criminal Procedure Code which functions to protect human rights comprehensively, in line with the demands of the Convention Against Torture, is a basic requirement towards the era of rule of law. So, the purpose of this article is to analyze the quality of the implementation of law enforcement that is not in accordance with the principles of law regarding the behavior of good law enforcement officials. The method used is qualitative with a sociolegal approach. The conclusion of this article is that one of the authority of legislation is its success in adapting to international conventions recognized by the affected people. The Criminal Procedure Code as an integral part of the national law of the Indonesian state law must be in line with Law No. 5 of 1998 concerning the Ratification of the Convention Against Torture. For this reason, looking at the weaknesses of the Criminal Procedure Code, both substantively and in practice, renovating the Criminal Procedure Code is urgent. The lack of perfection of the legal substance of the Criminal Procedure Code in providing human rights protection in a country that acts as a state of law is disastrous. In accordance with the rule of law, the law must recognize and guarantee human rights in order to establish a just order, because justice goes hand in hand with the structure of human rights.
\end{abstract}

Keywords: Criminal Procedure Code; Torture; Human Right; and Convention.

Cite This Article: Ibnu Artadi. (2019). "REFLECTION OF GLOBAL VALUES IN ANTITORTURE IN THE CRIMINAL PROCEDURE CODE." International Journal of Research - Granthaalayah, 7(11), 114-121. https://doi.org/10.29121/granthaalayah.v7.i11.2020.342.

\section{Introduction}

The ratification of the convention against torture by the Indonesian government into law is a commitment of adaptation to global trends and has an important meaning in the life of the nation and state in participating in creating world order, especially in increasing respect and upholding of human rights. Respect and advocacy of Human Rights has become "a global buzzworld" and acceptable in expressing human beings meaningfully: all human rights for all "[1], with whatever consequences are the typical conceptual format of a country with the rule of law -" rechtsstaat "-" 
the rule of law ", still has one primary goal: protection of human rights [2]. The level of protection of human rights will be a barometer of the identity of the "rule of law", a country that does not deserve to be called a rule of law, without human rights rechtsbescherming.

Law No. 8 of 1981 concerning Criminal Procedure Law is a juridical construction whose legalistic reality has provided "Ten Commandments" with the principle of protection of human rights in the "due process of law" that guarantees an honest trial, the principle of presumption of innocence, the right to privacy, the ethics of investigation and investigation and so on.

But ironically, mapping human rights violations in the form of forms of torture of suspects or those involved in criminal justice processes, for example in the form of ethical violations in the examination process, such as torture, interrogation with torture, manipulation of evidence continues to increase [3], especially the resolution of violence which was tainted during interrogation during the preliminary examination stage to the suspects and defendants.

Responding to the reality of the above with reference to the 21 years experience of the enactment of the Criminal Procedure Code, it is recognized that there are still many juridical technical problems and practices that still need improvement. For this reason, with the ratification of the Convention Against Torture ratified, the desire to conduct a review and amendment to the Criminal Procedure Code is an absolute necessity, as a consequence of our commitment to claim to be the rule of law.

\section{Method}

The approach method chosen in this study is sociolegal (socio-legal study). A study that reviews the law as a social fact that is observed in the natural experience as a pattern of behavior in the form of social institutions or social institutions, the study of law that conceptualizes and legalises the law as positive and empirical social facts [4]. As a consequence, this study tends to follow the paradigm of social facts that pay attention to the micro structure of society, using the theory of structural functionalism with interviews and questionnaires. The type of research used is qualitative research. According to Kirk and Miller that qualitative research is a certain tradition in social science that fundamentally depends on observing humans, both in its area and its terminology [5].

\section{Results and Discussions}

\subsection{Global Values in International Conventions and Criminal Procedure Reform}

\subsubsection{Harmonization of Global Values in International Conventions and National Law}

The swift current of globalization that has swept the world today, slowly but surely has caused changes in various aspects and dimensions of human life. The impact of the ease in disseminating information and communication opportunities and the development of transportation facilities, provides an opportunity for every human being to develop the scope of social relations, with a scope that is almost without knowing the national borders [6]. The development of opportunities to interact freely will encourage changes in the way of life of people in various countries. Because 
the impact of all of these earlier, basically can provide opportunities for the ongoing process of cultural transformation that is cross country and even across continents.

The characteristics that exist today, which distinguish the nature, ideology or outlook on life of a nation may only be left out. The contents may be the same, all just "label", and even have been abandoned by most adherents. This phenomenon of globalization has hit Indonesia which demands new values and norms in national and international life and also affects the life or formation of modern Indonesian law [7].

In this context, the development of Indonesian law will be characterized by energy that is not only in the form of basic values and instrumental values that are domestic, but also values that originate from international trends recognized by the adapting nations (the international trends of civilized nations) which often contain practical values in the framework of a pragmatic approach [8). This tendency is implicit and explicit in various international instruments such as: conventions, declarations, resolutions, "guidelines, codes of conduct, minimum standards of rules".

Adaptation to global trends is done through ratification of international conventions by law and by Presidential Decree. According to Patra [9], this does not conflict with national goals, because participating in creating world order is one of the pillars of national goals. Besides that, doctrinally taught that international treaties are one of the recognized legal elements, in addition to the law, jurisprudence, doctrine and customary law. Therefore, it can be concluded that the principles of international law are part of national law (the principles of international law are part of the law of the land).

However, it is of course necessary steps to harmonize the law on the basis of cultural relativism, which always takes into account the historical experience of the nation, the development of economic, social, political and cultural realities and the prevailing value system. In the context of this harmonization, steps which are anticipatory and proactive must be carried out systemically. For this reason, it is necessary to have an integrated International Convention Monitoring Team, which also includes the relevant ministries as well as relevant non-governmental organizations.

This is because often the policies that have been decided by international organizations under the United Nations are used as a basis for monitoring how far countries adhere to these international instruments. As an example, to evaluate the implementation of international instruments the United Nations Commission on Human Rights commissioned a "Special rapporteur". Indonesia has been evaluated by this special rapporteur, insofar as it concerns the Criminal Procedure Code with allegations of inhumane treatment (torture) in the administration of the criminal justice system [10].

Thus, adapting to various international trends (global trends) inevitably must be followed, but without having to sacrifice identity as a nation. In short, how to do legal harmonization between international instruments and national law, without leaving the basic values and instrumental values typical of the Indonesian nation. 


\subsubsection{Recommendations of the Convention Against Torture and the Urgency of Criminal Reform in Indonesia}

The ratification of the convention against torture by the Indonesian government becomes Law No. 5 of 1998 concerning the Convention Against Torture and Cruel Punishment is an adaptation step to global trends recognized by civilized nations in the world. Based on international customary methods which were then formulated in the "1969 Vienna Convention". Ratification is the third stage that must be passed by an international agreement, such as the "Convention Against Torture and Cruel Punishment" in order to have binding force. The two previous stages are the signing of the text of approval and approval by the institution in accordance with their respective constitutional. Beyond these three stages has external and internal legal consequences for the country that did it [11].

As a result of external law it is intended that the country concerned (Indonesia) has accepted all obligations imposed by the international agreement. While the consequences of internal law are an obligation for the country concerned (Indonesia) to change its national law in accordance with the intended international agreement [12]. The effect of this internal law is not limited to efforts to change national law to comply with the provisions of the international agreement referred to, but must also be accompanied by a guarantee that the national law will be applied consistently and or national law must be effective.

Thus, the ratification of the Convention Against Torture by Indonesia through the Act, then legally the provisions contained in the convention are part of national law that binds the state and society. However, the provisions in the Convention Against Torture cannot be operationalized directly to deal with cases of torture and violence committed by the state apparatus against the public.

This can happen because the Convention only regulates basic principles (rules) to protect the people from acts of torture and violence perpetrated by the state apparatus, both civilian and military. The basic rules do not regulate prohibited acts (criminal acts) accompanied by certain criminal sanctions. Besides that, the basic rules only contain rules that require the elaboration of the rules in the legislation. In the language of the Convention Against Torture, the main principles are recommended to be regulated in national law.

In Law Law No. 5 of 1998 concerning Ratification of the Convention Against Torture and Other Cruel, inhuman Or Degrading Treatment Or Punishment (Convention Against Torture and Other Cruel, Inhuman or Degrading Treatment or Punishment) there are four main recommendations that need to be adopted by domestic law, as following: First, Torture according to the provisions of the Convention is not only limited to physical torture, but also includes mental torture, acts of intimidation and coercion carried out by government officials and or at the encouragement or permission of government officials; Second, the state is obliged to take legislative, administrative, legal and other effective steps to prevent torture. Any statement made under persecution cannot be submitted as evidence in any process. Orders from superiors or authorities (public authority) also cannot be used as a justification for torture; Third, reform of torture arrangements which, according to the Convention's recommendations, must be made a criminal offense. That the participating countries review the preliminary examination system including the rules of interrogation, instructions, arrest, detention, search, seizure, imprisonment and treatment of people who were 
arrested, detained and imprisoned. Besides that, the state party includes torture as an extradicate crime; Fourth, for participating countries to provide compensation for victims of torture and have the right to receive fair and appropriate compensation including facilities for rehabilitation.

Responding to the four main recommendations in the Convention Against Torture mentioned above, and so that the Convention Against Torture can be operationalized in tackling practices of torture, violence and other cruelty, the provisions contained in the Convention must be spelled out in legislation or used or used to reform the laws and regulations that govern the problem. For this reason, by looking at the many problems in the application of the Criminal Procedure Code in practice, especially those tainted at the preliminary examination stage, there is no other way except to conduct a review and amendment to the Criminal Procedure Code. This is in line with what Justice Holmes said: "The life of the law has not been logic, it has been experience, legal life is not based on logic, but experience.

\subsection{Reflections on Global Values in the Convention Against Torture in the Criminal Procedure Code}

\subsubsection{Reflections on the Convention Against Torture in the Criminal Procedure Code}

One of the things that can reflect the authority of the legislation is the success of the legislation to be able to reflect international conventions that are recognized by the people according to the laws [13]. Adaptation National law to international conventions will be very meaningful, to help countries deal with crimes both on a national and international scale. One nation learns from other nations, both positive and negative in facing difficulties facing evil. Observing the above opinion and the background of various problems in the application of the Criminal Procedure Code in practice, especially those tainted at the preliminary examination stage, the relevant question to ask is whether the Criminal Procedure Code has reflected the recommendations of the Anti Torture convention.

As a juridical construction that revokes the enactment of "Het Herziene inlandsch Reglement" HIR (Staatsblad 1941 No. 44), the Criminal Procedure Code seeks to minimize human rights violations (suspects) that have often occurred. The Criminal Procedure Code is expected to bring new ideas to the breath of humanism and justice which is everyone's dream (to bring justice to the people). The value of justice and the breath of humanism KUHAP provides "ten commandments" as the principle of human rights protection in the "due process of law". From the "ten commandments" stated in the Criminal Procedure Code it is impressive that there is an optimization of protection by the Criminal Procedure Code for suspects and defendants.

Broadly speaking, the mapping of the Criminal Procedure Code in the preliminary examination process has provided human rights protection for suspects, and this has been in line and or has reflected the recommendations of the Anti Torture convention, although for that there is a need for reform, because there are still many weaknesses of the Criminal Procedure Code itself both substantively and in practice, aside from the absence of specific regulations regarding victims. This is in line with what was indicated by Syarif and Dadang [14] that the implementation of the Criminal Procedure Code was maximized, but the practice of violating human rights in the form of forms of torture against suspects or those involved in the criminal justice process in Indonesia 
continued. Therefore, in the midst of a wave of reforms, efforts to "renovate" the Criminal Procedure Code in order to provide optimal human rights protection in the preliminary process of examining suspects and victims of crime proportionally are urgent.

\subsubsection{Implementation of the Convention Against Torture in the Criminal Procedure Code}

Now this is contextual momentum to voice the slogan: Renewing the Criminal Procedure Code must be a priority. The steps to improve the Criminal Procedure Code by borrowing measures from the changes to the Law from Elsam [15], that in the context of changing the Criminal Procedure Code, the first step is: through a global approach that is an overall change to the content of the Criminal Procedure Code and then an evolutionary approach, namely to make updates or amendments to some of the contents of the Criminal Procedure Code which are considered inadequate. By paying attention to the draft 2000 Criminal Procedure Code, the changes to the Criminal Procedure Code are carried out evolutionarily. Therefore, in revising the Criminal Procedure Code there are several things that need to be considered by the legislative body, in connection with the ratification of the Convention on Torture and the practice of the Criminal Procedure Code, especially at the preliminary examination stage.

In accordance with the recommendations of the Anti Torture Convention so that participating countries review the preliminary examination system, the striking weakness in the Criminal Procedure Code lies in the surveillance sector. Direct supervision of the investigative apparatus in the preliminary examination process is only in his supervisor (vertical supervision). In practice vertical supervision is not effective enough, because of the culture of the corps (organization) to always maintain the good name and prestige of the organization in the eyes of the community.

In addition, another weakness lies in the absence of institutions that can test the validity of the actions of investigators who arbitrarily search and seize suspects' property, under the pretext of obtaining evidence. The initial concept of the Criminal Procedure Code had initially led to an oversight body by the "Judge Commissioner", which aimed to prevent the violation of the rights of the suspect in the preliminary examination process. But in the course of its final discussion the Criminal Procedure Code gave rise to a "Pre-Judicial" institution which was expected to run in accordance with the principles of due process of law. However, in reality the pre-judicial institution only has limited authority on the examinating judge, namely the authority to supervise the implementation of a small part of the coercive effort of the investigator, which is only to test the validity of the arrest and detention.

While most other forced efforts are not under the authority of this institution. The validity of evidence from investigators or public prosecutors obtained illegally, such as: the information of suspects obtained by torture is not the authority of the Pre-Judicial institution. The existence of a pre-trial institution that is no longer in line with the initial concept has resulted in violations of the implementation of forced efforts often in the preliminary examination process. Just look at a concrete example, the Jagorawi Toll Road robbery incident that killed the driver and key witnesses who were named suspects. Witness Tjeje Tadjudin was tortured outside the limits of humanity which resulted in his death. 
The limitations of the Pre-Judicial Institution to test the validity of the evidence obtained by torture for trial before the trial need to be addressed by expanding the existing authority in line with the role of the Judge Commissioner. It seems that efforts to renovate the Criminal Procedure Code are non-negotiable needs, so that the ratification of the Convention Against Torture can not only be carried out in full, but also this nation's commitment to respecting and upholding Human Rights and at the same time a barometer of identity in line with the identity of "rechstaat" and "The rule of law".

\section{Conclusion}

As the final conclusion of the discussion, it is necessary to introduce a basic assumption: one of the authority of the legislation is its success in adapting to international conventions recognized by the affected people. The Criminal Procedure Code as an integral part of the national law of the Indonesian state law must be in line with Law No. 5 of 1998 concerning the Ratification of the Convention Against Torture. For this reason, looking at the weaknesses of the Criminal Procedure Code, both substantively and in practice, renovating the Criminal Procedure Code is urgent. The lack of perfection of the legal substance of the Criminal Procedure Code in providing human rights protection in a country that acts as a state of law is disastrous. In accordance with "the rule of law", the law must recognize and guarantee human rights in order to establish a just order, because justice goes hand in hand with the structure of human rights. The realization of the Criminal Procedure Code which functions to protect human rights comprehensively (both suspects and victims of crime), in line with the demands of the Convention Against Torture, besides being able to minimize the occurrence of acts of torture in the preliminary examination process, is also a basic requirement towards the era of rule of law.

\section{References}

[1] Hidayat, Nurkholis dan Restaria F. Hutabarat (ed). 2012, Mengukur Realitas dan Persepsi Penyiksaan di Indonesia Melalui Indeks Penyiksaan dan Indeks Persepsi Penyiksaan, Jakarta: The Partnership for Governance Reform.

[2] Philip M Hardjon. 1995. Negara Hukum dan Hak-hak Dasar Fakultas Hukum, Surabaya: Universitas Airlangga

[3] Mulyana W Kusuma. 1997. Refleksi akhir tahun 1997 bidang politik, Hukum Dan Kebudayaan: Jalan Mewujudkan HAM belum lapang, Jawa Pos.

[4] Ronny Hanitijo Soemitro. 1990. Metodologi Penelitian Hukum dan Jurimetri, Jakarta: Ghalia Indonesia.

[5] Daud Silalahi. 2001. Tipologi Penelitian Hukum, Preferensi Khusus pada Pendekatan multi/interdisipliner, Lawencon Binding Centre.

[6] Muladi, dan Barda Nawawi Arief. 1992. Bunga Rampai Hukum Pidana, Bandung: Alumni.

[7] George Ritzer. 2003. Sosiologi Ilmu Pengetahuan Berparadigma Ganda. Jakarta: Raja Grafindo Persada, Jakarta.

[8] Muladi. 1995. Kapita Selekta Sistem Peradilan Pidana, Semarang: Universitas Diponegoro.

[9] Patra, Rommy, 2018, "The Failure of Settlement of Human Rights Violations In Indonesia and It's Solutions", Yustisia Law Journal, Volume 1, Number 1, January-April, h. 197-215.

[10] Eddyono, Supriyadi Widodo, dkk, 2014, Indonesia Pro Penyiksaan: 16 Tahun Pasca Ratifikasi Konvensi Anti Penyiksaan di Indonesia, Catatan Untuk Peringatan Hari Anti penyiksaan Internasional 2014, Jakarta: WGAT. 
[11] Kontras, 2015, Laporan Kronik Penyiksaan 2014-2015: Mendelegitimasikan Praktik Penyiksaan di Indonesia, Jakarta: Kontras.

[12] Wiranata, Agung Yudha, 2007, Konvensi Anti Penyiksaan, Seri Bahan Bacaan Kursus HAM untuk Pengacara XI Tahun 2007, Jakarta: Elsam.

[13] Subiyanto, Achmad Edi, 2011, "Perlindungan Hak Konstitusional Melalui Pengaduan Konstitusional", Jurnal Konstitusi, Volume 8, Nomor 5, Oktober, h. 707-731.

[14] Syarif, Laode M., dan Dadang Trisasongko (ed), 2012, Jalan Panjang Penghapusan Penyiksaan, Jakarta: Kemitraan bagi Pembaruan Tata Pemerintahan.

[15] Elsam, 2013, Pandangan Mengenai Situasi Hak Asasi Manusia 2013: Hak-hak Dasar di bawah Ancaman Eskalasi Kekerasan, Jakarta: Elsam

*Corresponding author.

E-mail address: annemaryani0@gmail.com 